\title{
DETEKSI PINEAP PADA FIRMWARE WIFI PINEAPPLE MENGGUNAKAN SMARTPHONE BERBASIS ANDROID
}

\author{
Fahmi Romisa1, Bambang Sugiantoro² \\ 1romy.rockwell@gmail.com, 2bambang.sugiantoro@uin-suka.ac.id \\ ${ }^{1}$ Magister Teknik Informatika Universitas Islam Indonesia, ${ }^{2}$ Teknik Informatika UIN Sunan Kalijaga \\ Yogyakarta
}

\begin{abstract}
Abstrak
Kebutuhan akan akses jaringan nirkabel atau wireless saat ini sangat dibutuhkan oleh hampir semua orang, hampir di semua tempat terdapat akses jaringan wifi. Sebuah ilmu penetrasi jaringan semakin lama selama meningkat, tidak hanya menggunakan suatu penetrasi yang menggunakan perangkat lunak, tetapi sudah merambah ke perangkat keras yang sudah berubah fungsi, tidak lagi berfungsi sebagai menyebar sebuah koneksi data, tetapi sudah merambah sebagai alat penetrasi jaringan, sistem ini berguna untuk mendeteksi adanya sebuah router yang dapat menduplikasi semua router sekitar dengan permintaan probe request, maka dari itu diperlukan suatu alat pendeteksian yang dapat mendeteksi secara real time terhadap router tersebut. Penelitian ini menghasilkan suatu alat pendeteksian yang user friendly menggunakan smartphone berbasis android, beserta analisis dan melakukan suatu uji beda pada router yang memiliki firmware wifi pineapple yang memiliki core pineap.
\end{abstract}

Kata kunci: Deteksi, Jaringan nirkabel, Wifi Pineapple, Pineap.

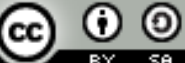

ILKOM Jurnal Ilmiah work is licensed under a CCA-SA 4.0 International License.

\section{Pendahuluan}

Menurut sebuah survey yang berasal dari laporan Fortinet, yang menyebutkan bahwa jaringan nirkabel merupakan infrastruktur IT yang paling rentan terhadap berbagai serangan, disusul dengan endpoint, core network, database, aplikasi, email, dan media penyimpanan[1]. Perkembangan openwrt tanpa henti berdampak pada evolusi penggunaan router. Router tidak lagi hanya untuk menyebar sebuah koneksi data, tetapi sudah merambah ke berbagai fungsi diluar fungsi tersebut. Beberapa darinya digunakan untuk melakukan penetrasi terhadap suatu jaringan. Kebanyakan dari orang awam dalam membangun suatu jaringan tidak memperhatikan sisi keamanannya, terutama dalam membangun suatu jaringan nirkabel atau wireless.

Saat ini sistem untuk mendeteksi adanya pineap atau rogue access point pada router sangat minim, sebagai contoh pendeteksian yang dibuat oleh Neha Agrawal, \& Shashikala Tapaswi, yang menggunakan pendekatan hybrid dan sistem deteksi anomaly, pendeteksian tersebut tidak memiliki user interface yang mudah digunakan, sistem tersebut hanya mendeteksi kegiatan yang mencurigakan melalui lalu lintas pada suatu jaringan[2]. Sistem pendeteksian lainnya dibuat oleh Asaf Tzur dkk, dengan melakukan eliminasi, untuk tujuan keamanan pada sebuah organisasi, dengan menggunakan metode autonomous Direction Finding (DF), yaitu, suatu alat yang dapat mengidentifikasi Angle of Arrival (AoA), dalam menerima sinyal wifi, menggunakan standar komunikasi jaringan nirkabel, seperti Wi-Fi (IEEE 802.11n).

Kontribusi utama dalam penelitian teresbut yaitu melakukan pendekatan dari beberapa antena penerima, dengan OFDM Channel State Information (CSI) sebagai dasar untuk menerapkan alat interferometry DF. Pendekatan ini secara teoristis diselidiki melalui analisis numerik, dan validasi oleh alat prototype [3]. Sistem yang ditawarkan saat ini belum adanya suatu sistem deteksi yang user friendly terhadap pengguna, seperti menggunakan suatu metode pendekatan, tidak mendeteksi secara real time yang berisi informasi pendukung, dan secara manual melalui proses yang cukup rumit. Hasil akhir dari penelitian ini berupa solusi terbaik dan penting untuk mendeteksi adanya pineapp atau fake probe request yang berada disekitar, yaitu dengan menggunakan smartphone berbasis android, yang dapat mendeteksi secara real time. Beserta analisis jaringan pada router tersebut, lalu mengumpulan data eksperimen pada penyebaran beacon frame dengan uji t. 


\section{Landasan Teori}

\subsection{Cybercrime}

Cybercrime didefinisikan sebagai kejahatan di mana komputer adalah objek kejahatan tersebut dengan menggunakan teknik seperti hacking, phishing, spam, dan sebagainya. Pelaku cybercrime dapat menggunakan teknologi komputer untuk mengakses informasi pribadi, rahasia dagang bisnis, atau menggunakan internet yang bertujuan untuk eksploitatif. Penjahat juga dapat menggunakan komputer sebagai alat bantu penyadapan alat komunikasi dan dokumen atau penyimpanan suatu data. Penjahat yang melakukan kegiatan ilegal seperti ini sering disebut sebagai hacker. Cybercrime juga dapat disebut sebagai kejahatan komputer.

Cybercrime dapat diklasifikasikan menjadi 3 kategori yaitu [3]:

1. Terhadap individu

Ini adalah kejahatan atau tindakan yang berkomitmen terhadap seseorang. Kejahatankejahatan ini termasuk pelecehan melalui e-mail, cyber stalking, penyebaran materi cabul di internet atau intranet, pencemaran nama baik, hacker/cracking, dll. di samping itu, ini termasuk kejahatan terhadap kekayaan dari seorang individu, vandalisme komputer, dan transmisi virus. Penyusupan Internet dan pengendalian yang tidak sah atas sistem komputer.

2. Terhadap organisasi

kejahatan yang memiliki komitmen terhadap organisasi termasuk departemen pemerintah, perusahaan swasta, perusahaan, kelompok individu. Distribusi perangkat lunak bajakan juga bisa dimasukkan dalam kategori ini sebagai kejahatan cyber.

3. Terhadap masyarakat luas

Ini adalah tindak kejahatan yang berdampak bahwa masyarakat luas pada umumnya. Contohnya pornografi merupakan contoh khas dari kejahatan tersebut.

\subsection{Probe request}

Probe request merupakan suatu respon yang dikirimkan yang dapat memeriksa apakah ada suatu jaringan wireless yang tersedia atau tidak, ada dua mode yaitu directed dan broadcast. Mode directed meminta suatu jaringan yang tersedia yang tersedia, yang telah digunakan sebelumnya, dan beberapa permintaan untuk pemeriksaan beberapa jaringan yang ada. Mode broadcast yaitu hanya satu permintaan yang dikirim pada setiap jaringan yang ada, dan diharapkan dapat merespon.

Komparasi pada mode tersebut, mode directed yang lebih rentan terhadap serangan, karena beberapa SSID dapat menghubungkan seseorang dari lokasi yang berbeda. Gambar 1 menunjukan perbedaan tersebut [4].

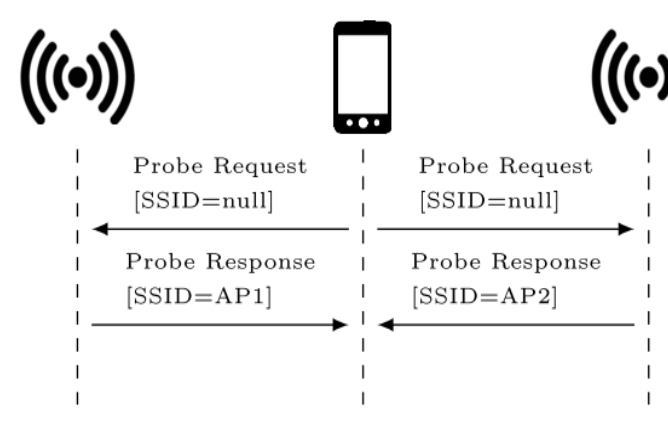

(a) Broadcast Probe Request

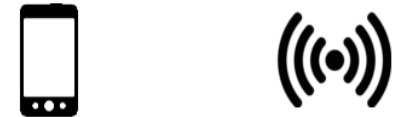

Probe Request $[\mathrm{SSID}=\mathrm{AP} 1]$

Probe Response $[\mathrm{SSID}=\mathrm{AP} 1]$

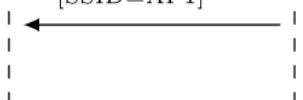

(b) Directed Probe Request

Gambar 1. Perbedaan broadcast probe request dan directed probe request

\subsection{PineAP}

PineAp merupakan module pada wifi pineapple yang dapat mengomatisasi serangan MITM terhadap klien. Perangkat nirkabel mengirimkan permintaan probe request dari Preferred Network List pada perangkat nirkabel ke area sekitar, perangkat android mengirimkan permintaan tersebut secara terus menerus. Misalnya apakah ada jaringan rumah disini?, apakah ada jaringan kerja disini ?. perangkat akan terus melakukan pengiriman permintaan probe request dari Preferred Network List pada setiap perangkat, ketika perangkat nirkabel mengkonfirmasi adanya jaringan yang tersimpan di PNL maka akan secara otomatis akan terhubung[5].

PineAP terdiri dari sejumlah komponen: 
1. PineAP merupakan salah satu rangkaian alat

2. Dogma yang berfungsi untuk mengirimkan beacon kedalam daftar SSID perangkat device sekitar.

3. Beacon merespon untuk mengikuti semua probe request dengan sejumlah beacon yang menanggapi permintaan client.

4. Harvester mengumpulkan semua SSID yang dapat digunakan untuk Dogma.

\section{Metode}

Penelitian ini menggunakan beberapa tahapan metode, yang dapat dilihat pada gambar 2 dibawah ini.

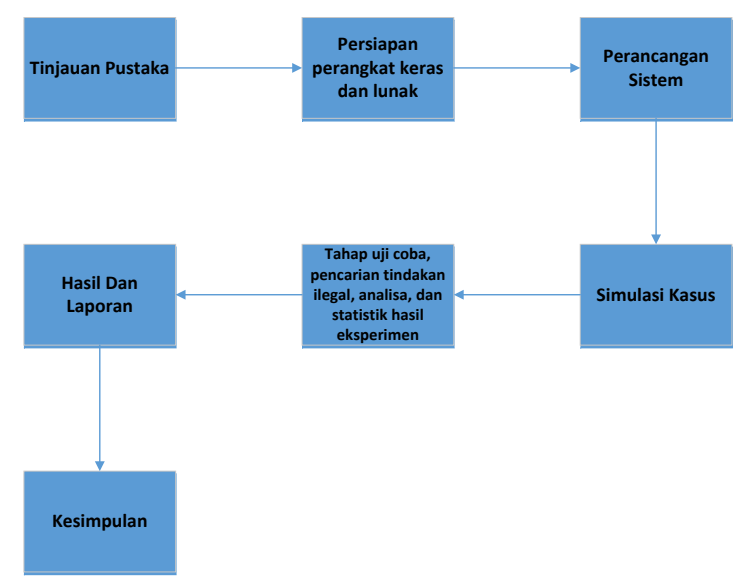

Gambar 2. Metodologi Penelitian

Menunjukan penelitian ini menggunakan 7 tahapan metodologi penelitian yaitu.

1. Literature Review

2. Preparation : Hardware and Software

3. System Planning

4. Simulation Case

5. The test phase, the search for illegal actions, analysis, statistics and experimental results

6. Results and Reports

7. Conclusion

\section{Hasil}

\subsection{Deteksi}

Fungsi mulai file berfungsi untuk melakukan suatu perintah scanning pada jaringan sekitar berbasis wireless, apakah kemungkinan adanya rogue access point, dengan pemberitahuan berupa notifikasi. dan berhenti adalah suatu perintah yang berfungsi untuk menghentikan semua proses scanning pada jaringan wireless sekitar, dalam menu tersebut terdapat frekuensi pencarian yang dapat di ubah nilainya dalam satuan detik, beserta time stamp kapan sistem tersebut dimulai, dan list hasil BSSID beserta level sinyal dalam dBm, beserta notifikasi pada gambar 3 .

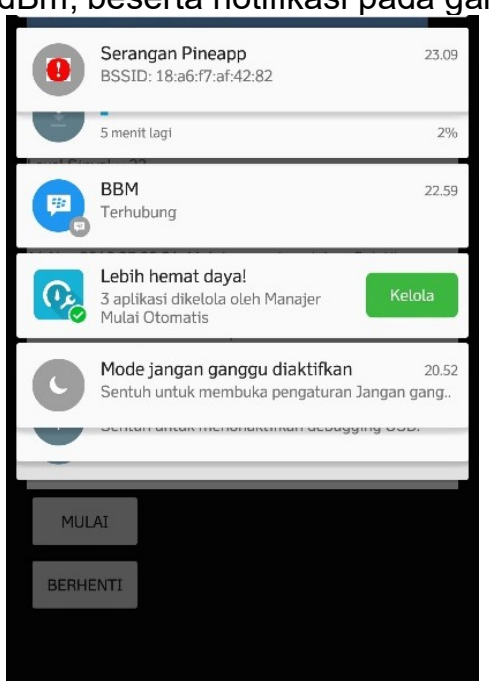


Gambar 3. Tampilan GUI Aplikasi

Sistem tersebut menampilan pemberitahuan berupa notifikasi yang berisi informasi, berupa mac address atau BSSID pada router yang berusaha melakukan serangan terhadap jaringan wireless di sekitarnya. BSSID pada router tersebut 18:a6:f7:af:42:82.

\subsection{Analisis}

Pencarian tindakan illegal dimulai dengan menggunakan tool aplikasi Net Surveyor, yaitu dengan mengetahui secara spesifik informasi berupa SSID, BSSID, Channel, Beacon, kualitas sinyal dan enkripsi. Karena informasi yang didapat sebelumnya yaitu berupa BSSID, dan BSSID tidak mungkin di duplikasi oleh seseorang, terkecuali duplikasi pada SSID pada sebuah router, maka dari itu informasi BSSID merupakan hal yang valid dalam membedakan sebuah router.Pada hasil pendeteksian sebelumnya diketahui bahwa BSSID yang dicurigai sebagai rogue access point atau yang dapat menduplikasi semua access point disekitarnya adalah 18:a6:f7:af:42:82 .

\subsection{Network Discovery}

\begin{tabular}{|c|c|c|c|c|}
\hline SSID & BSSID & Channel & RSSI (dBm) & Security \\
\hline Pineapple & $e 6: 95: 6 e: 40: 67: 57$ & 11 & -40 & YES \\
\hline Ersyada Putra & e $8: 94: f 6: f c: f 1: b a$ & 6 & -56 & YES \\
\hline UNKNOWN_SSID_e $4: 95: 6 \mathrm{e}: 40: 67: 57$ & $e 4: 95: 6 e: 40: 67: 57$ & 11 & -40 & None \\
\hline Kos $1 \mathrm{MBps}$ & $c 4: a 3: 66: b c: 4 c: 38$ & 11 & -67 & YES \\
\hline UNKNOWN SSID $18: a 6:$ f $7:$ af: $42: 82$ & $18: a 6: f 7:$ af: $42: 82$ & 11 & -30 & None \\
\hline Wifi Id 10000 & ac: $64: 62: d c: 09: 36$ & 1 & -90 & YES \\
\hline UNKNOWN_SSID_ac: $64: 62:$ dc: $09: 38$ & ac: $64: 62:$ dc $: 09: 38$ & 1 & -100 & YES \\
\hline UII ACCSESS FTSP & $\mathrm{d} 0: 5 \mathrm{~b}: \mathrm{a} 8: \mathrm{d} 3: \mathrm{d} 2: \mathrm{af}$ & 11 & -100 & YES \\
\hline
\end{tabular}

Gambar 4. List SSID

Pada gambar 5 terlihat pada top remote IP address by total traffic (packets), IP address 216.58.196.4 merupakan IP address yang selalu melakukan conversation terhadap pengguna yaitu IP Address pengguna adalah 192.168.1.185. dan pada gambar 6 domain yang paling tinggi melakukan conversation adalah mobile.facebook.com.
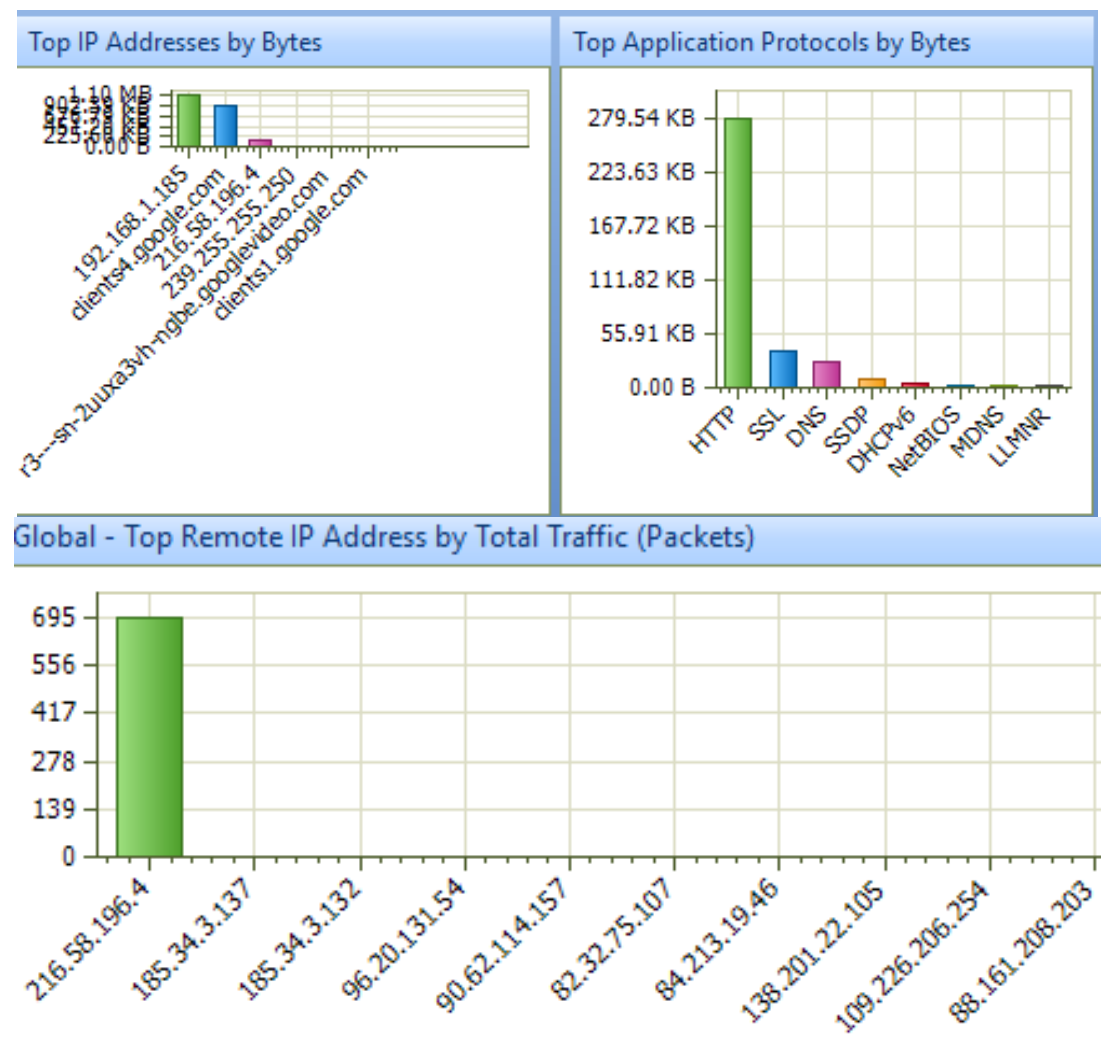

Gambar 5. Trafik Jaringan 


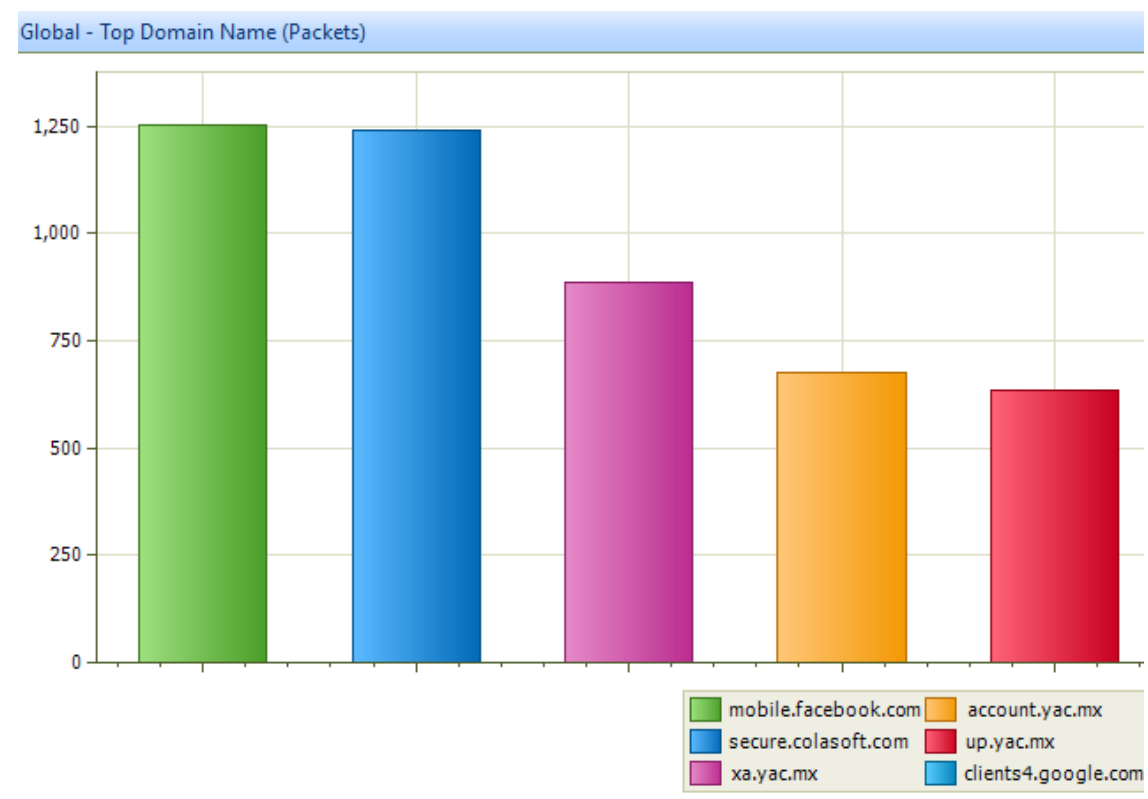

Gambar 6. Top Domain

Setelah melakukan percobaan akses terhadap IP Address 216.58.196.4 ternyata langsung menampilkan suatu halaman website phising, urlnya yaitu mobile.facebook.com/login.html terlihat pada gambar 7 berikut.

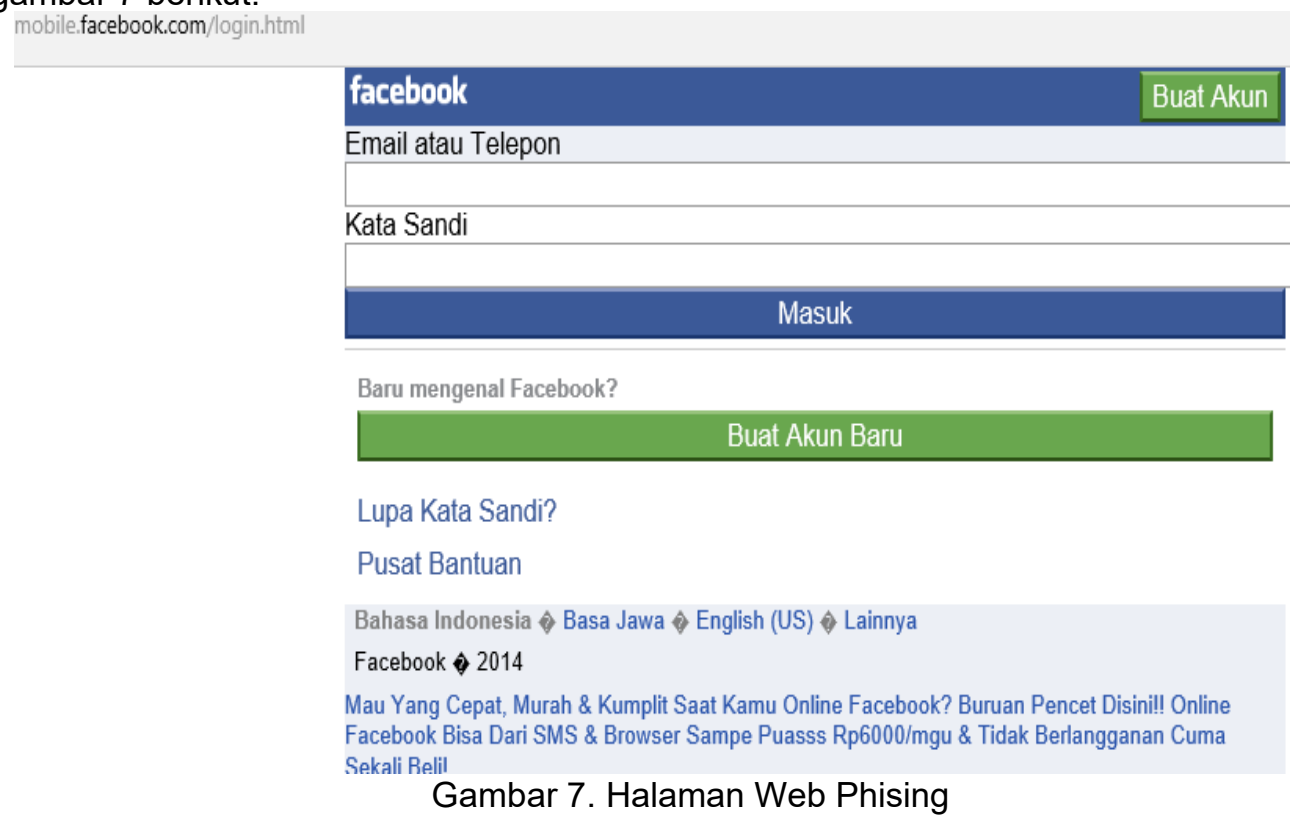

Analisis selanjutnya menggunakan tool wireshark yaitu melakukan filter pada IP pengguna 192.168.1.185. dengan menggunakan perintah ip.addr $==192.168 .1 .185$ filter tersebut berguna untuk mengetahui seberapa banyak conversation pada ip address tersebut terhadap IP address lainnya. Gambar 8 terlihat permintaan suatu proses antara IP address 192.168.1.1 ke 192.168.1.185 melalui protocol HTTP menggunakan HTTP/1.1 berbasis text/html. 


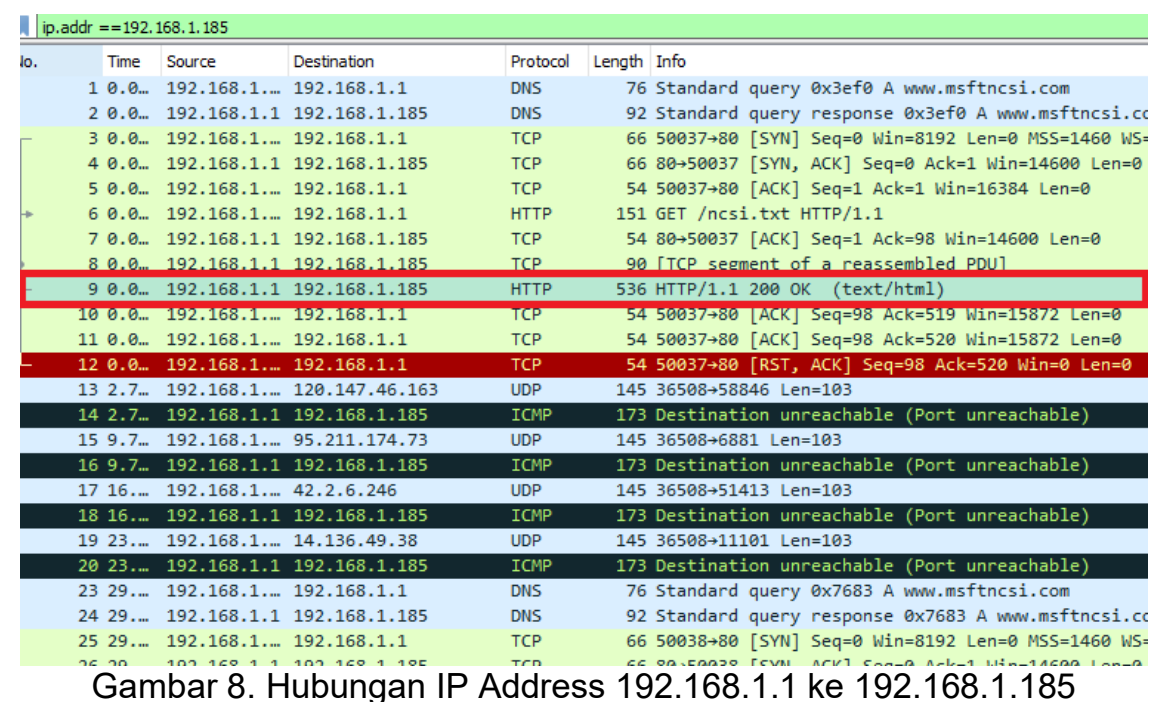

Pada Gambar 8 terlihat IP Address 192.168.1.1 mengirimkan sebuah halaman website terhadap IP Address 192.168.1.185 yang dibuktikan dengan adanya suatu syntax berbasis html yang dikirimkan.

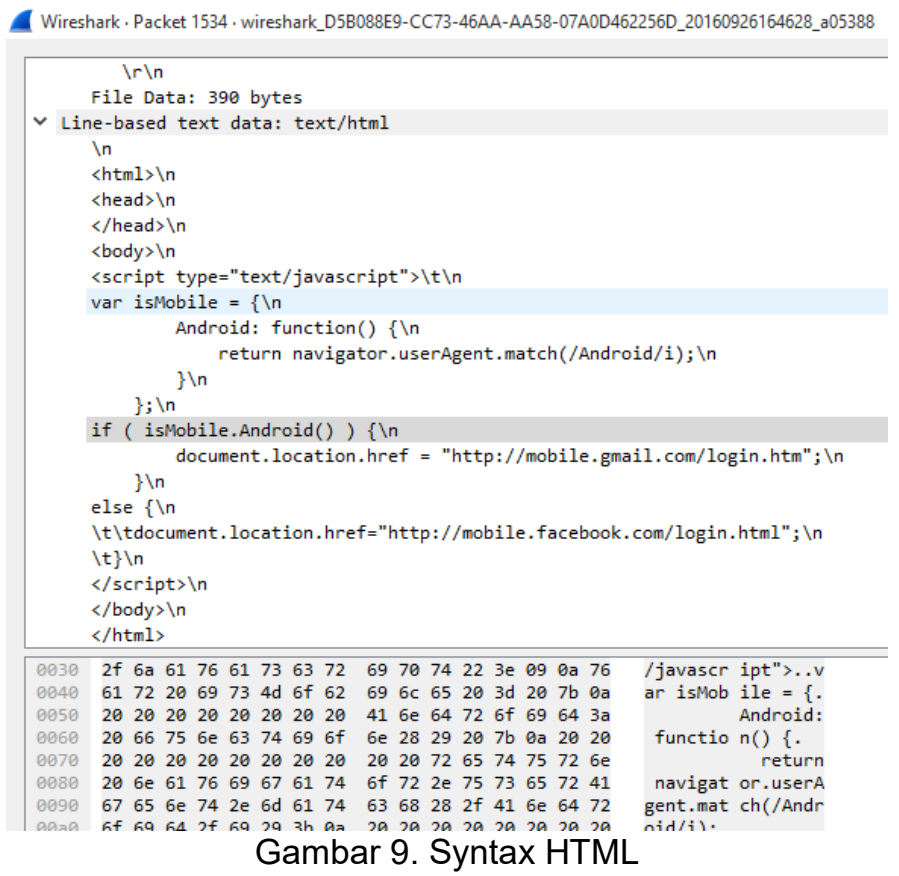

\subsection{Pengumpulan Data Eksperimen}

Karena beacon frame merupakan hal yang penting pada suatu router dalam penyebaran informasi termasuk melakukan probe request authentication and association pada device sekitar, maka dari itu pengumpulan data bertujuan untuk mengetahui suatu proses yang berjalan sebanyak 30 kali pengulangan pada kedua firmware dengan waktu interval setiap 15 menit, beacon frame yang digunakan sebagai data yaitu beacon frame yang menyentuh angka minimal 80 ke atas, yang bertujuan untuk mengetahui apakah penyeberan beacon frame pada router penyerang sama dengan penyebaran beacon frame pada firmware wifi pineapple nano atau tidak.

Dari 30 data yang ada, selanjutnya mencari nilai rata-rata pada data, yang dibagi menjadi enam data dari setiap lima data rekapitulasi yang ada pada tabel 1 dan tabel 2.

Tabel 1. penyebaran beacon frame firmware penyerang

\begin{tabular}{llll}
\hline P1 & 79.4 & P4 & 77.6 \\
P2 & 73.6 & P5 & 76.4 \\
\hline
\end{tabular}




\begin{tabular}{cccc}
\hline P3 & 76.4 & P6 & 78 \\
\hline & & & \\
Tabel 2. Rata-rata penyebaran & Beacon & frame & firmware wifi pineapple nano \\
N1 & 84.8 & N4 & 81.6 \\
N2 & 78 & N5 & 76.6 \\
N3 & 83.2 & N6 & 75 \\
\hline
\end{tabular}

Hipotesis:

H0 : Penyebaran beacon frame pada firmware penyerang (pineapple mark III) = Penyebaran beacon frame pada firmware wifi pineapple nano.

$\mathrm{H} 1$ : Penyebaran beacon frame pada firmware penyerang (pineapple mark III) $\neq$ Penyebaran beacon frame pada firmware wifi pineapple nano.

Taraf kepercayaan sebesar $99 \%$ atau 0,09 dengan tingkat kepercayaan $1 \%$ atau 0,01 .

\section{a. Uji Normalitas}

Uji Normalitas pada setiap variable beacon frame dapat di lihat pada tabel 3 berikut;

Tabel 3 tabel uji normalitas

\begin{tabular}{|c|c|c|c|c|c|c|c|}
\hline & & \multicolumn{2}{|c|}{ Kolmogorov-Smirnov } & \multicolumn{4}{|c|}{ Shapiro-Wilk } \\
\cline { 3 - 7 } & Firmware & Statistic & Df & Sig. & $\begin{array}{c}\text { Statisti } \\
\text { C }\end{array}$ & df & Sig. \\
\hline $\begin{array}{c}\text { Ratar } \\
\text { atape } \\
\text { nyeb } \\
\text { aran }\end{array}$ & $\begin{array}{c}\text { Firmware } \\
\text { Penyerang }\end{array}$ & .233 & 6 & $.200^{*}$ & .949 & 6 & .733 \\
\cline { 2 - 7 } & $\begin{array}{c}\text { Firmware } \\
\text { wifi } \\
\text { pineapple } \\
\text { nano }\end{array}$ & .184 & 6 & $.200^{*}$ & .941 & 6 & .665 \\
\hline
\end{tabular}

Metode analitis menggunakan Shapiro-Wilk, Pada kedua variabel tersebut menunjukan bahwa nilai signifikansi Shapiro-Wilk lebih dari 0.05 , jadi kedua data variable tersebut di asumsikan berdistribusi normal, dan dapat dilakukan suatu uji $t$ dua sampel independen (independent sample t-test).

b. Uji T Dua Sampel Independen (Independent Sample T Test)

Uji normalitas pada data masing-masing variable beacon frame firmware penyerang (mark III) dan firmware wifi pineapple nano telah memenuhi syarat untuk dilakukannya uji $\mathrm{T}$ dua independent (Independent sample t-test) yaitu angka signifikansinya $\mathbf{0 . 7 3 3}$ dan $\mathbf{0 . 6 6 5}$, pada tabel 4 berikut hasil uji hipotesis pada kedua variabel;

Tabel 4 Independent Sample T-Test

\begin{tabular}{|c|c|c|c|c|c|c|c|c|}
\hline \multicolumn{2}{|c|}{$\begin{array}{l}\text { Levene's } \\
\text { Test for } \\
\text { Equality of } \\
\text { Variances }\end{array}$} & \multicolumn{7}{|c|}{ t-test for Equality of Means } \\
\hline \multirow[b]{2}{*}{$\mathrm{F}$} & \multirow[b]{2}{*}{ Sig. } & \multirow[b]{2}{*}{$\mathrm{t}$} & \multirow[b]{2}{*}{ df } & \multirow{2}{*}{$\begin{array}{l}\text { Sig. (2- } \\
\text { tailed) }\end{array}$} & \multirow{2}{*}{$\begin{array}{c}\text { Mean } \\
\text { Difference }\end{array}$} & \multirow{2}{*}{$\begin{array}{l}\text { Std. Error } \\
\text { Difference }\end{array}$} & \multicolumn{2}{|c|}{$\begin{array}{c}99 \% \text { Confidence Interval } \\
\text { of the Difference }\end{array}$} \\
\hline & & & & & & & Lower & Upper \\
\hline 6.508 & .029 & -1.662 & 10 & .128 & -2.9667 & 1.7854 & -8.6252 & 2.6919 \\
\hline & & -1.662 & $\begin{array}{r}7.38 \\
2 \\
\end{array}$ & .138 & -2.9667 & 1.7854 & -9.1062 & 3.1728 \\
\hline
\end{tabular}

Selang kepercayaan yang dikehendaki sebesar 99\%, 100-99 = 1\% atau 0.01 jadi signifikan levelnya adalah 0,01 , yang menentukan apakah $\mathrm{HO}$ diterima jika nilai sig. $>0,01$ atau sebaliknya $\mathrm{HO}$ ditolak jika nilai sig. < 0,01, bila HO ditolak maka konsekuensinya hipotesis alternatif $\mathrm{H} 1$ diterima. 
Dari hasil pengujian tersebut terlihat nilai signifikan menunjukan angka 0.029 , nilai tersebut lebih besar dari 0.01 yang berarti $\mathrm{HO}$ diterima, yaitu penyebaran beacon frame pada firmware penyerang (pineapple mark III) = penyebaran beacon frame pada firmware wifi pineapple nano. Jadi penyebaran beacon frame pada firmware penyerang (wifi pineapple mark III) sama dengan penyebaran beacon frame yang dimiliki oleh firmware wifi pineapple nano yang sangat berguna untuk melakukan probe request authentication and association pada device sekitar.

\section{Kesimpulan dan Saran}

\subsection{Kesimpulan}

1. Penelitian yang telah dilakukan menghasilkan suatu alat pendeteksian yang cukup mudah untuk mendeteksi adanya suatu permintaan probe request, yang bersifat dapat menduplikasi access point di sekitarnya berupa informasi BSSID yang valid untuk membedakan access point di sekitarnya.

2. Firmware wifi pineapple mark III memiliki mini web server 1.0 yang merupakan server ringan HTTP berbasis Bahasa $\mathrm{C}$, yang berguna untuk melakukan phising pada suatu website.

3. Penyebaran beacon frame pada firmware penyerang (wifi pineapple mark III) sama dengan penyebaran beacon frame yang dimiliki oleh firmware wifi pineapple nano yang sangat

5.2 Saran berguna untuk melakukan probe request authentication and association pada device sekitar.

1. Alat pendeteksian menggunakan berbagai macam sistem operasi khususnya pada smartphone berbasis ios maupun sistem operasi blackberry yang dapat mendeteksi serangan.

2. Device wifi pineapple yang menggunakan alat terbaru dan firmware terbaru.

3. Analisa forensik dari sisi hardware maupun syntax pada firmware wifi pineapple.

\section{Daftar Pustaka}

[1] Fortinet. (2015). Wireless Security Survey 2015.

https://www.fortinet.com/content/dam/fortinet/assets/analyst-reports/Survey-ReportWirelessSecurity-Survey-2015-v3.pdf, diakses 20 April 2016.

[2] Agrawal, N., \& Tapaswi, S., 2015, Wireless Rogue Access Point Detection Using Shadow Honeynet. http://doi.org/10.1007/s11277-015-2408-0.

[3] Tzur, A., Amrani, O., \& Wool, A. 2015. Direction Finding of rogue Wi-Fi access points using an offthe-shelf MIMO - OFDM receiver. Physical Communication, 17, 149-164. http://doi.org/10.1016/j.phycom.2015.08.010.

[4] Barbera, M. V, Epasto, A., Mei, A., Perta, V. C., \& Stefa, J. (2013). Signals from the Crowd: Uncovering Social Relationships through Smartphone Probes

[5] John Wang. (2012). Advancing the Service Sector with Evolving Technologies: Techniques and Principles : Business Science Reference (an imprint of IGI Global)

[6] License, I. (2016). An Augmented Penetration Testing Framework for Mobile Devices on 802 . 11 ac Wireless Networks, 0-76. 